

\title{
Fruit Powder as Natural Preservatives for Raw Chevon
}

\section{G. Mahapatra* and S. Biswas}

Department of Livestock Products Technology, Faculty of Veterinary and Animal Sciences, West Bengal University of Animal and Fishery Sciences, 68, Kshudiram Bose Sarani, Kolkata, West Bengal (700 037), India

6 Corresponding Author

G. Mahapatra e-mail: drgargimahapatra@gmail.com

Citation: Mahapatra and Biswas, 2019. Fruit Powder as Natural Preservatives for Raw Chevon. International Journal of Bio-resource and Stress Management 2019, 10(3):276-281. HTTPS://DOI.ORG/10.23910/ IJBSM/2019.10.3.1988b

Copyright: (c) 2019 Mahapatra and Biswas. This is an open access article that permits unrestricted use, distribution and reproduction in any medium after the author(s) and source are credited.

Data Availability Statement: Legal restrictions are imposed on the public sharing of raw data. However, authors have full right to transfer or share the data in raw form upon request subject to either meeting the conditions of the original consents and the original research study. Further, access of data needs to meet whether the user complies with the ethical and legal obligations as data controllers to allow for secondary use of the data outside of the original study.

Funding: The funding was provided from the university research grant provided by the West Bengal University of Animal and Fishery Sciences.

Conflict of interests: There is no conflict of interest with the authors in publishing this article in content and form with the available data

\begin{abstract}
Meat has high moisture content and is a rich source nutrients, making it vulnerable to spoilage. Meat preservation is largely based on chemical preservatives but prolonged intake of such chemicals may be hazardous to human health. This study focuses on utilization of fruit powders as meat preservatives. Starfruit (Averrhoa carambola) and guava (Psidium guajava) powder were added to raw minced chevon at the rate of $1.0 \%, 1.5 \%$ and $2.0 \%$ on $\mathrm{w} / \mathrm{w}$ basis. The preservation effect of these additives on chevon stored at refrigeration temperature $\left(4 \pm 1{ }^{\circ} \mathrm{C}\right)$ was determined by analyzing the effect of these powders on the lipid oxidation rate and microbial quality. For determining the rate of lipid-oxidation thiobarbituric acid reacting substances (TBARS) value was determined whereas to determine the microbial quality of meat total plate count (TPC), total psychrotrophic count (TPSC), total coliform count (TCC) and yeast and mouldcount (YMC) were determined. These studies were conducted on $0,3,7,14$ and 21 day of refrigerated storage. Compared to control, the starfruit and guava powder treated samples had significantly lower $(p<0.05)$ TBARS values hence indicated delayed development of rancidity extending the shelf-life from 14 to 21 days of refrigerated storage. Similarly, the fruit powder treated samples had significantly lowered $(p<0.05)$ total plate count and total psychrotrophic count increasing the shelf-life to 7 days of refrigerated storage. The fruit powders were capable of inhibiting coliform and yeast and mould growth till the $3^{\text {rd }}$ day of refrigerated storage. Hence, it could be inferred that both starfruit and guava powder can successfully be utilized as natural preservative for minced chevon storage.
\end{abstract}

Keywords: Minced chevon, starfruit powder, guava powder, antioxidant, anti-microbial

\section{Introduction}

Meat is a concentrated source of nutrients and has a crucial role to play in human nutrition. It is rich in proteins of high biological value, vitamins and essential micronutrients (Pereira and Vicente, 2013). Due to high moisture and nutrient content meat acts as a good substrate for breeding of pathogenic and non-pathogenic microorganisms ultimately leading tospoilage (Zhang et al., 2009). Fat is also an essential component in meat and is responsible for quality characteristics such as juiciness, texture, meaty flavor, cooking yield and characteristic aroma (Choi et al., 2013). Lipid oxidation is another form of spoilage observed in meat (Kanner, 1994). Meat preservation has largely been dependent

\section{Article History \\ RECEIVED in $24^{\text {th }}$ April 2019 RECEIVED in revised form $17^{\text {th }}$ June 2019 ACCEPTED in final form $21^{\text {st }}$ June 2019}


on synthetically derived antibiotics and anti-oxidants. These preservatives being chemically derived are a source of concern because in long run they may be hazardous to human health (Ahmad et. al., 2015). Hence there is a shift of focus from artificial/chemical derived preservatives to natural substitutes.

Manufacturers prefer natural preservatives over synthetic ones as the later require expensive testing and their use might be objected to consumers (Haumann, 1990). In the agricultural food-processing sector by-products viz. fruit pomace, seeds, peels, pulps, unused flesh, and husks are generated. These residues are attractive sources of natural antioxidants and dietary fiber (Hemaida, 1994); phenolic compounds (polyphenols, tannins, and flavonoids) and many other bioactive components that have several functionalities including antimicrobial activity (Balasundram et al., 2006 and Tiwari et al., 2009). Starfruit (Averrhoa carambola) is a very good source of natural antioxidants like L-ascorbic acid, epicatechin and gallic acid in gallotannin forms (Guanghou et al., 2004) and its methanolic extract has demonstrated antimicrobial activity by inhibit the growth of various Gram +ve bacteria, Gram-ve bacteria and fungi (Masum et al., 2007). Similarly, guava (Psidium guajava) exhibits anti-oxidant property due to the presence of bioactive compounds and phenolic compounds viz. flavonoids, carotenoids, anthocyanins ,terpenoids,myricetin, triterpenes, apigenin and ellagic acid (Misra and Seshadri, 1968; Jime' nez-Escrig et al., 2001 and Miean et al., 2001). The Ethanolic extract of the ripe guava is known to exhibited anti-microbial activity against Streptococcus mutans and Escherichia coli (Neira et al., 2005).

Raw minced chevon has a short shelf-life especially due to its comminuted form. Prior to storage at refrigerated $\left(4 \pm 1{ }^{\circ} \mathrm{C}\right)$ temperature the comminuted raw meat was treated with Starfruit powder (SP) and Guava powder (GP). The effect of SP and GP on the lipid oxidation rate and microbial quality of the product was evaluated for a period of 21 days.

\section{Materials and Methods}

The investigation was performed between November 2017 and February 2019. For this purpose medium ripe starfruit and guava were purchased from local market as per their seasonal availability. The fruits were washed, cleaned and dried. Thin transverse slices were cut which were dried separately in a hot air oven at $47 \pm 2{ }^{\circ} \mathrm{C}$ for $24 \mathrm{hrs}$. These dehydrated fruit slices were ground to a fine powder, sieved using a fine mesh and finally stored at $-18 \pm 1{ }^{\circ} \mathrm{C}$ packed aerobically in UV sterilized Low Density Polyethylene (LDPE) containers, until further utilization.

Freshly cut chevon samples were collected from slaughter houses run by the government of West Bengal and visible fat was removed. All goats slaughtered belonged to Black Bengal breed, were aged around 10-12 months and weighed around 12-15 kgs (live weight). Even though the samples were collected on random selection basis emphasis was given towards keeping maximum homogeneity, particularly from the points of its origin. The lean meat was minced in two steps, firstly by using $10 \mathrm{~mm}$ plate and then subsequently by a $5 \mathrm{~mm}$ plate. To the minced meat starfruit powder (SP) and Guava powder (GP) were added on w/w basis at the rate of $0 \%$ for control (RC), $1.0 \%$ SP for treatment 1 (RS1), $1.5 \%$ SP for treatment 2 (RS2), 2.0\% SP for treatment 3( RS3), $1.0 \%$ GP for treatment 4 (RG1), 1.5\% GP for treatment 5 (RG2) and 2.0\% GP for treatment 6 (RG3).

$\mathrm{pH}$ determination for the fruit powders was done as per $\mathrm{AOAC}(1995)$ and was recorded using a digital $\mathrm{pH}$ meter. $\mathrm{pH}$ was determined only for day zero. The anti-oxidant effect of the fruit powders on raw minced chevon was analyzed by estimating the Thiobarbituric Acid Reacting Substances (TBRAS) values (Tarladgis et al., 1960) whereas the anti-microbial ability was determined by estimating Total Plate Count (TPC), Total Psychrotrophic Count (TPSC), Total Coliform Count (TCC) and Yeast and Mould Count (YMC) (APHA, 2001). These studies were conducted on day $0,3,7,14$ and 21 of refrigerated $\left(4 \pm 1^{\circ} \mathrm{C}\right)$ storage. For all the microbiological analysis readymade media from Hi-Media Laboratories (P Ltd., Mumbai, were used.

For this study six sets of experiments were conducted and each experiment had been replicated four times making $\mathrm{n}=24$. All data obtained during this investigation were analyzed statistically by using SPSS $-24^{\circ}$ software package. All data were analysed using two-way ANOVA with interaction taking treatment and storage time as main effects whereas for $\mathrm{pH}$ related values the analysis was made by one-way ANOVA. To compare means, Duncan's multiple range test (Duncan, 1955) was adopted. For analysis of data related to different criteria of sensory evaluation The Kruskal-Wallis $\mathrm{H}$ test (Kruskal and Wallis, 1952) was adopted. The values were presented as mean along with standard error (Mean \pm SE) and significance level was identified at the $95 \%$ confidence level $(p<0.05)$.

\section{Results and Discussion}

The $\mathrm{pH}$ value for SP and GP are presented in Table 1. The $\mathrm{pH}$ values observed for the fruit powder were in coherence with the observations made by Correia Da Costa et al. (2008) and

\begin{tabular}{lc}
\hline \multicolumn{3}{l}{ Table 1: $\mathrm{pH}$ of starfruit powder and guava powder (mean $\pm \mathrm{SE})$} \\
\hline $\mathrm{pH}$ of starfruit powder & $\mathrm{pH}$ of guava powder \\
\hline $3.62 \pm 0.041$ & $4.3467 \pm 0.040$ \\
\hline
\end{tabular}

$\mathrm{n}=24$; All values were recorded on day zero

Patil et al. (2010). The effect of SP and GP on lipid oxidation rate in raw minced meat stored at refrigerated $\left(4 \pm 1{ }^{\circ} \mathrm{C}\right)$ temperature are presented in Table 2 . The values recorded were statistically significant $(p<0.05)$ and with each passing day a significant increase $(p<0.05)$ was observed. The control 
Table 2: Thiobarbituric acid reacting substances (TBRAS) values for raw minced chevon treated with starfruit powder and guava powder stored at refrigerated $\left(4 \pm 1^{\circ} \mathrm{C}\right)$ temperature (mean $\left.\pm \mathrm{SE}\right)$

\begin{tabular}{lccccc}
\hline & \multicolumn{5}{c}{ TBARS Values $\left(\mathrm{mg} \mathrm{mda} \mathrm{kg}{ }^{-1}\right)$} \\
\hline Treatment & \multicolumn{5}{c}{ Storage Days } \\
\cline { 2 - 5 } & Day 0 & Day 3 & Day 7 & Day 14 & Day 21 \\
\cline { 2 - 5 } RC & $0.579 \pm 0.027^{\mathrm{eA}}$ & $0.969 \pm 0.019^{\mathrm{dA}}$ & $1.546 \pm 0.024^{\mathrm{cA}}$ & $1.946 \pm 0.022^{\mathrm{bA}}$ & $2.445 \pm 0.029^{\mathrm{aA}}$ \\
RS1 & $0.584 \pm 0.026^{\mathrm{eA}}$ & $0.842 \pm 0.029^{\mathrm{dC}}$ & $1.411 \pm 0.028^{\mathrm{cC}}$ & $1.762 \pm 0.028^{\mathrm{bB}}$ & $2.166 \pm 0.03^{\mathrm{aB}}$ \\
RS2 & $0.574 \pm 0.032^{\mathrm{eB}}$ & $0.782 \pm 0.035^{\mathrm{dE}}$ & $1.337 \pm 0.025^{\mathrm{cE}}$ & $1.737 \pm 0.036^{\mathrm{bC}}$ & $1.975 \pm 0.034^{\mathrm{aD}}$ \\
RS3 & $0.569 \pm 0.028^{\mathrm{eB}}$ & $0.658 \pm 0.028^{\mathrm{dG}}$ & $1.253 \pm 0.032^{\mathrm{cG}}$ & $1.63 \pm 0.026^{\mathrm{bE}}$ & $1.935 \pm 0.031^{\mathrm{aE}}$ \\
RG1 & $0.578 \pm 0.026^{\mathrm{eA}}$ & $0.877+0.0275^{\mathrm{dB}}$ & $1.431+0.027^{\mathrm{cB}}$ & $1.78 \pm 0.034^{\mathrm{bB}}$ & $2.157 \pm 0.032^{\mathrm{aB}}$ \\
RG2 & $0.581 \pm 0.045^{\mathrm{eA}}$ & $0.817 \pm 0.032^{\mathrm{dD}}$ & $1.375 \pm 0.028^{\mathrm{cD}}$ & $1.756 \pm 0.029^{\mathrm{bB}}$ & $2.082 \pm 0.034^{\mathrm{aC}}$ \\
RG3 & $0.566 \pm 0.031^{\mathrm{eC}}$ & $0.721 \pm 0.028^{\mathrm{dF}}$ & $1.324 \pm 0.032^{\mathrm{cF}}$ & $1.715 \pm 0.027^{\mathrm{bD}}$ & $1.868 \pm 0.037^{\mathrm{aF}}$ \\
\hline
\end{tabular}

$\mathrm{n}=24$; All treatment groups were under refrigerated storage $\left(4 \pm 1^{\circ} \mathrm{C}\right)$; $\mathrm{RC}$ - control raw minced meat, $\mathrm{RS} 1: 1.0 \% \mathrm{SP}$ treatment; RS2: $1.5 \%$ SP treatment; RS3: 2.0\% SP treatment; RG1: $1.0 \%$ GP treatment; RG2: 1.5\% GP treatment; RG3: $2.0 \%$ GP treatment; Data (mean $\pm S E$ ) with different small letter superscripts in the same row differ significantly $(p<0.05)$; Data (mean $\pm S E)$ with different capital letter superscripts in the same column differ significantly $(p<0.05)$

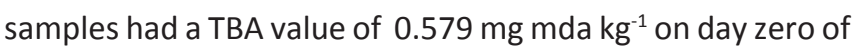
refrigerated storage which rose to $2.445 \mathrm{mg} \mathrm{mda} \mathrm{kg}^{-1}$ on $21^{\text {st }}$ day. Meat samples start exhibiting rancid flavour when MDA concentration rises above $0.6 \mathrm{mg} \mathrm{kg}^{-1}$ (Georgantelis et al., 2007) and after reaching a threshold limit value for rancidity of $2 \mathrm{mg} \mathrm{kg}^{-1}$ they are considered to be spoilt (Verma and Sahoo, 2000). The control meat samples were considered as spoilt after $14^{\text {th }}$ day of refrigerated storage. Addition of SP and GP to raw minced meat indicated a trend where TBA values would decrease with increase in percentage of SP and GP incorporation. It was observed that addition of SP at $1.5 \%$ and $2.0 \%$ and of GP at $2.0 \%$ delayed the spoilage to post $21^{\text {st }}$ day of refrigerated storage. The trend for effectiveness in reduction of TBA values was SP $2.0 \%>$ GP $2.0 \%>$ SP $1.50 \%>$ GP $1.50 \%>$ SP $1.0 \%>$ GP $1.0 \%>$ Control. Eventhough, the initial TBA values did not differ significantly ( $p>0.05$ ) for control, 1.0\% SP treatment, 1.5\% GP treatment and $2.0 \%$ GP treatment and for $1.5 \%$ and $2.0 \%$ SP treatment but for the 21st day of storage all values differed significantly $(p<0.05)$ except for $1.0 \% \mathrm{SP}$ and $1.0 \% \mathrm{GP}$ treatment. Both starfruit and guava are rich in vitamin $\mathrm{C}$, dietary fiber and phenolic compound which are instrumental towards its strong antioxidant activity (Shuiand Leong, 2006 and Jime nez-Escrig et al., 2001). Similarly, Devatkal et al. (2014) observed that addition pomegranate peel extract to ground goat meat and observed a reduction of $41 \%$ in TBARS values. Biswas et al. (2012) demonstrated the same in ground pork on addition of curry leaf and mint leaf extract and Tang et al. (2001) in beef, pork, poultry and seafood on addition of tea catechins.

Effect of SP and GP on Total Plate Count (TPC), Total Psychrotrophic Count (TPSC), Total Coliform Count (TCC) and Yeast and Mould Count (YMC) of raw minced chevon stored at refrigerated temperature of $(4 \pm 1){ }^{\circ} \mathrm{C}$ is presented in Table 3, 4, 5 and 6, respectively. The values were recorded on $0,3,7,14$ and 21 of storage.

Addition of SP and GP resulted in significant $(p<0.05)$ reduction in TPC, TPSC, TCC and YMC values. Jay (1992) has stated that the spoilage in meat becomes evident when the surface microbial count reaches $7 \log _{10} \mathrm{cfu} \mathrm{g}^{-1}$. Observing Table 3 it was established that no significant difference $(p>0.05)$ was observed for the initial microbial load but it was conclusive that the samples indicated spoilage post the $7^{\text {th }}$ day of refrigerated storage. Taking the $7^{\text {th }}$ day of refrigeration into account on treatment of raw minced chevon with $1.0 \%$ SP, $1.50 \%$ SP, $2.0 \%$ SP, $1.0 \%$ GP, $1.50 \%$ and $2.0 \%$ GP reduced the TPC by $10.4 \%, 16.25 \%, 24.91 \%$, $7.45 \%, 13.28 \%$ and $23.43 \%$ respectively.. Based on the TPC values the trend observed for the antimicrobial quality of the samples was SP $2.0 \%>$ GP $2.0 \%>$ SFP $1.50 \%>$ GP $1.50 \%>$ SFP $1.0 \%>$ GP $1.0 \%>$ Control. Observing Table 4 , it was concluded that compared to control samples the TPSC values indicated a drop in count by $5.88 \%$ for $1.0 \%$ SP treatment, $11.77 \%$ for $1.5 \%$ SP treatment, $15.65 \%$ for $2.0 \%$ SP treatment, $4.94 \%$ for $1.0 \%$ GP treatment, $10.73 \%$ for $1.5 \%$ GP treatment and $13.69 \%$ for $2.0 \%$ GP treatment on the 21 st day of storage. No significant difference $(p>0.05)$ was observed in TPSC values for $1.0 \% \mathrm{SP}$ treatment and 1.0\% GP treatment on day zero of refrigerated storage and for $1.0 \% \mathrm{SP}$ treatment and $1.0 \%$ GP treatment as well as for $1.5 \% \mathrm{SP}$ treatment and $1.5 \% \mathrm{GP}$ treatment on day 21 of refrigerated storage. An observation similar to these findings was made by Govaris et al. (2010) who studied the effect of oregano essential oil on minced sheep meat stored at $4{ }^{\circ} \mathrm{C}$ and by Devatkal et al. (2014) who studied the antimicrobial effect of pomegranate peel on ground goat meat stored at $(4 \pm 1){ }^{\circ} \mathrm{C}$. Analyzing Table 5 and 
Table 3: Effect of addition of starfruit powder and guava powder on the total plate count (TPC) values for raw minced chevon stored at refrigerated $\left(4 \pm 1^{\circ} \mathrm{C}\right)$ temperature (mean $\left.\pm \mathrm{SE}\right)$

\begin{tabular}{lccccc}
\hline & \multicolumn{5}{c}{ TPC values $\left(\log _{10}\right.$ cfu g $\left.^{-1}\right)$} \\
\hline Treatment & \multicolumn{5}{c}{ Storage Days } \\
\cline { 2 - 5 } & Day 0 & Day 3 & Day 7 & Day 14 & Day 21 \\
\hline RC & $2.851 \pm 0.028^{\mathrm{eA}}$ & $4.65 \pm 0.029^{\mathrm{dA}}$ & $6.854 \pm 0.025^{\mathrm{cA}}$ & $10.248 \pm 0.027^{\mathrm{bA}}$ & $16.547 \pm 0.026^{\mathrm{aA}}$ \\
RS1 & $2.845 \pm 0.028^{\mathrm{eA}}$ & $4.25 \pm 0.027^{\mathrm{dC}}$ & $6.141 \pm 0.023^{\mathrm{cC}}$ & $9.15 \pm 0.026^{\mathrm{bC}}$ & $15.946 \pm 0.025^{\mathrm{aB}}$ \\
RS2 & $2.845 \pm 0.027^{\mathrm{eA}}$ & $3.652 \pm 0.025^{\mathrm{dE}}$ & $5.74 \pm 0.023^{\mathrm{cE}}$ & $8.444 \pm 0.026^{\mathrm{bE}}$ & $13.35 \pm 0.025^{\mathrm{aD}}$ \\
RS3 & $2.837 \pm 0.023^{\mathrm{eA}}$ & $3.149 \pm 0.026^{\mathrm{dG}}$ & $5.147 \pm 0.024^{\mathrm{cG}}$ & $7.849 \pm 0.025^{\mathrm{bG}}$ & $11.952 \pm 0.028^{\mathrm{aF}}$ \\
RG1 & $2.848 \pm 0.026^{\mathrm{eA}}$ & $4.35 \pm 0.026^{\mathrm{dB}}$ & $6.343 \pm 0.028^{\mathrm{cB}}$ & $9.555 \pm 0.026^{\mathrm{bB}}$ & $16.045 \pm 0.029^{\mathrm{aB}}$ \\
RG2 & $2.85 \pm 0.026^{\mathrm{AA}}$ & $3.747 \pm 0.022^{\mathrm{dD}}$ & $5.944 \pm 0.03^{\mathrm{cD}}$ & $8.848 \pm 0.027^{\mathrm{bD}}$ & $13.847 \pm 0.026^{\mathrm{aC}}$ \\
RG3 & $2.848 \pm 0.026^{\mathrm{eA}}$ & $3.252 \pm 0.027^{\mathrm{dF}}$ & $5.248 \pm 0.028^{\mathrm{cF}}$ & $8.247 \pm 0.027^{\mathrm{bF}}$ & $12.455 \pm 0.025^{\mathrm{aE}}$ \\
\hline
\end{tabular}

$\mathrm{n}=24$; All treatment groups were under refrigerated storage $\left(4 \pm 1^{\circ} \mathrm{C}\right.$ ); Data (mean $\pm \mathrm{SE}$ ) with different small letter superscripts in the same row differ significantly $(p<0.05)$; Data (mean $\pm S E$ ) with different capital letter superscripts in the same column differ significantly $(p<0.05)$

Table 4: Effect of addition of starfruit powder and guava powder on the total psychrotopic count (TPSC) values for raw minced chevon stored at refrigerated $\left(4 \pm 1^{\circ} \mathrm{C}\right)$ temperature (mean $\left.\pm \mathrm{SE}\right)$

\begin{tabular}{lccccc}
\hline \multirow{5}{*}{ Treatment } & \multicolumn{5}{c}{ TPSC values $\left(\log _{10}\right.$ cfu $\left.^{-1}\right)$} \\
\cline { 2 - 5 } & Day 0 & Day 3 & Day 7 & Day 14 & Day 21 \\
\hline RC & $4.641 \pm 0.03^{\mathrm{eA}}$ & $6.245 \pm 0.029^{\mathrm{dA}}$ & $7.152 \pm 0.028^{\mathrm{cA}}$ & $8.649 \pm 0.028^{\mathrm{bA}}$ & $10.254 \pm 0.026^{\mathrm{aA}}$ \\
RS1 & $4.249 \pm 0.029^{\mathrm{eB}}$ & $5.852 \pm 0.028^{\mathrm{dC}}$ & $6.448 \pm 0.026^{\mathrm{cC}}$ & $8.156 \pm 0.027^{\mathrm{bB}}$ & $9.651 \pm 0.028^{\mathrm{aB}}$ \\
RS2 & $3.844 \pm 0.027^{\mathrm{eE}}$ & $5.147 \pm 0.025^{\mathrm{dE}}$ & $5.942 \pm 0.028^{\mathrm{cE}}$ & $7.65 \pm 0.027^{\mathrm{bC}}$ & $9.047 \pm 0.024^{\mathrm{aC}}$ \\
RS3 & $3.348 \pm 0.028^{\mathrm{eF}}$ & $4.848 \pm 0.023^{\mathrm{dF}}$ & $5.449 \pm 0.028^{\mathrm{cG}}$ & $7.147 \pm 0.026^{\mathrm{bE}}$ & $8.649 \pm 0.026^{\mathrm{aE}}$ \\
RG1 & $4.248 \pm 0.027^{\mathrm{eB}}$ & $5.955 \pm 0.024^{\mathrm{dB}}$ & $6.751 \pm 0.027^{\mathrm{cB}}$ & $8.249 \pm 0.026^{\mathrm{bB}}$ & $9.747 \pm 0.026^{\mathrm{aB}}$ \\
RG2 & $4.145 \pm 0.027^{\mathrm{eC}}$ & $5.252 \pm 0.027^{\mathrm{dD}}$ & $6.348 \pm 0.026^{\mathrm{cD}}$ & $7.652 \pm 0.029^{\mathrm{bC}}$ & $9.154 \pm 0.024^{\mathrm{aC}}$ \\
RG3 & $3.941 \pm 0.027^{\mathrm{eD}}$ & $4.847 \pm 0.028^{\mathrm{dF}}$ & $5.654 \pm 0.027^{\mathrm{cF}}$ & $7.345 \pm 0.026^{\mathrm{bD}}$ & $8.85 \pm 0.025^{\mathrm{aD}}$ \\
\hline
\end{tabular}

$\mathrm{n}=24$; All treatment groups were under refrigerated storage $\left(4 \pm 1^{\circ} \mathrm{C}\right)$; Data (mean $\pm S E$ ) with different small letter superscripts in the same row differ significantly $(p<0.05)$; Data (mean $\pm S E$ ) with different capital letter superscripts in the same column differ significantly $(p<0.05)$

Table 6 it was conclusive that in general raw minced meat would exhibit coliform and yeast and mould growth post day zero of refrigerated storage but on treatment with SP and GP coliform and yeast and mould growth was inhibited till the $3^{\text {rd }}$ day of refrigerated storage and comparing the mean values it was noted that $2.0 \% \mathrm{SP}$ treated samples yielded the best results. The trend observed for TCC and YMC values, indicating inhibition of microbial growth were SP $2.0 \%>S P$ $1.50 \%>\mathrm{SP} \quad 1.0 \%>\mathrm{GP} \quad 2.0 \%>\mathrm{GP} \quad 1.50 \%>\mathrm{GP} \quad 1.0 \%>$ Control . Similar observations were made by Hsouna et al. (2011) who studied the antimicrobial effect of essential oil of Ceratonia siliqua pod in minced beef and Banon et al. (2007) who studied the antimicrobial effect of grape seed and green tea extracts on raw beef patties. Thomas et al. (2016) also studied the antimicrobial effect of starfruit juice on pork nuggets and observed similar results. This antimicrobial effect of SP and GP on raw minced chevon was due to the the combined effect of low $\mathrm{pH}$ of the fruit powders and presence of anti-microbial components like flavones and glycosides (Payal et al., 2012) in SP and flavonoids, carotenoids and phenols (Miean et al., 2001) in GP. Moreover methanolic extracts of starfruit were evaluated for antimicrobial activity against gram positive bacteria, gram negative bacteria, yeast and fungi (Masum et al., 2007) and Neira et al. (2005) had reported that ethanolic extract from the shell of ripe guava fruit helps in preventing activity on Streptococcus mutans and Escherichia coli. Both these factors combined improved the microbial quality of the refrigerated product by prolonging the lag phase and retarding the log phase of microbial multiplication. 
Table 5: Effect of addition of starfruit powder and guava powder on the total coliform count (TCC) values for raw minced chevon stored at refrigerated $\left(4 \pm 1^{\circ} \mathrm{C}\right)$ temperature (mean $\left.\pm \mathrm{SE}\right)$

\begin{tabular}{lccccc}
\hline & \multicolumn{5}{c}{ TCC values $\left(\log _{10} \mathrm{cfu} \mathrm{g}^{-1}\right)$} \\
\hline Treatment & \multicolumn{5}{c}{ Storage Days } \\
\cline { 2 - 6 } & Day 0 & Day 3 & Day 7 & Day 14 & Day 21 \\
\hline RC & N.D. & $1.251 \pm 0.028^{\mathrm{dA}}$ & $1.547 \pm 0.026^{\mathrm{cA}}$ & $1.952 \pm 0.024^{\mathrm{bA}}$ & $2.35 \pm 0.026^{\mathrm{aA}}$ \\
RS1 & N.D. & N.D. & $1.275 \pm 0.011^{\mathrm{cD}}$ & $1.575 \pm 0.011^{\mathrm{bD}}$ & $1.875 \pm 0.011^{\mathrm{aD}}$ \\
RS2 & N.D. & N.D. & $1.243 \pm 0.033^{\mathrm{cE}}$ & $1.542 \pm 0.032^{\mathrm{bE}}$ & $1.83 \pm 0.031^{\mathrm{aE}}$ \\
RS3 & N.D. & N.D. & $1.225 \pm 0.011^{\mathrm{cF}}$ & $1.525 \pm 0.011^{\mathrm{bE}}$ & $1.825 \pm 0.011^{\mathrm{aE}}$ \\
RG1 & N.D. & N.D. & $1.375 \pm 0.011^{\mathrm{cB}}$ & $1.775 \pm 0.011^{\mathrm{bB}}$ & $1.975 \pm 0.011^{\mathrm{aB}}$ \\
RG2 & N.D. & N.D. & $1.363 \pm 0.012^{\mathrm{cB}}$ & $1.762 \pm 0.012^{\mathrm{bB}}$ & $1.964 \pm 0.013^{\mathrm{aB}}$ \\
RG3 & N.D. & N.D. & $1.325 \pm 0.011^{\mathrm{cC}}$ & $1.725 \pm 0.011^{\mathrm{bC}}$ & $1.925 \pm 0.011^{\mathrm{aC}}$ \\
\hline
\end{tabular}

$\mathrm{n}=24$; All treatment groups were under refrigerated storage $\left(4 \pm 1^{\circ} \mathrm{C}\right)$; Data (mean $\pm \mathrm{SE}$ ) with different small letter superscripts in the same row differ significantly $(p<0.05)$; Data (mean $\pm S E$ ) with different capital letter superscripts in the same column differ significantly $(p<0.05)$

Table 6: Effect of addition of starfruit powder and guava powder on the yeast and mould count (YMC) values for raw minced chevon stored at refrigerated $\left(4 \pm 1^{\circ} \mathrm{C}\right)$ temperature (mean $\left.\pm \mathrm{SE}\right)$

\begin{tabular}{lccccc}
\hline & \multicolumn{5}{c}{ YMC values $\left(\log _{10} \mathrm{cfu} \mathrm{g}^{-1}\right)$} \\
\hline Treatment & \multicolumn{5}{c}{ Storage Days } \\
\cline { 2 - 6 } & Day 0 & Day 3 & Day 7 & Day 14 & Day 21 \\
\hline RC & N.D. & $1.145 \pm 0.032^{\mathrm{dA}}$ & $1.641 \pm 0.031^{\mathrm{cA}}$ & $1.943 \pm 0.03^{\mathrm{bA}}$ & $2.14 \pm 0.03^{\mathrm{aA}}$ \\
RS1 & N.D. & N.D. & $1.275 \pm 0.011^{\mathrm{cC}}$ & $1.675 \pm 0.012^{\mathrm{bE}}$ & $1.875 \pm 0.011^{\mathrm{aD}}$ \\
RS2 & N.D. & N.D. & $1.258 \pm 0.013^{\mathrm{cC}}$ & $1.658 \pm 0.013^{\mathrm{bE}}$ & $1.857 \pm 0.013^{\mathrm{aD}}$ \\
RS3 & N.D. & N.D. & $1.225 \pm 0.011^{\mathrm{cD}}$ & $1.625 \pm 0.011^{\mathrm{bF}}$ & $1.825 \pm 0.011^{\mathrm{aE}}$ \\
RG1 & N.D. & N.D. & $1.575 \pm 0.011^{\mathrm{cB}}$ & $1.775 \pm 0.011^{\mathrm{bB}}$ & $1.975 \pm 0.011^{\mathrm{aB}}$ \\
RG2 & N.D. & N.D. & $1.555 \pm 0.012^{\mathrm{cB}}$ & $1.746 \pm 0.024^{\mathrm{bC}}$ & $1.958 \pm 0.012^{\mathrm{aB}}$ \\
RG3 & N.D. & N.D. & $1.525 \pm 0.011^{\mathrm{cB}}$ & $1.721 \pm 0.011^{\mathrm{bD}}$ & $1.921 \pm 0.011^{\mathrm{aC}}$ \\
\hline
\end{tabular}

$\mathrm{n}=24$; All treatment groups were under refrigerated storage $\left(4 \pm 1^{\circ} \mathrm{C}\right)$; Data (mean $\pm \mathrm{SE}$ ) with different small letter superscripts in the same row differ significantly $(p<0.05)$; Data (mean $\pm S E$ ) with different capital letter superscripts in the same column differ significantly $(p<0.05)$

\section{Conclusion}

Storage stability and shelf life of raw minced chevon can be enhanced by addition of starfruit and guava powder.

\section{Further Research}

Other than choosing higher levels of SP and GP incorporation, the effect of vacuum and modified atmospheric packaging on the anti-oxidant and anti-microbial properties of the fruit powder can be analyzed. The active principles present in the fruit powders along with other similar fruits can be identified and a study on molecular level can be conducted to enrich the findings of this study.

\section{References}

AOAC., 1995. Official Methods of Analysis, $16^{\text {th }}$ Ed.,
Association of Official Analytical Chemists, Arlington, VA.

APHA, 2001. American public health association. In: Frances, P.D., Keith, I. (Eds.), Compendium of Methods for the Microbiological Examination of Foods. Washington, DC.

Ahmad, S.R., Gokulakrishnan, P., Giriprasad, R., Yatoo, M.A., 2015. Fruit based natural antioxidants in meat and meat products: A Review, Critical Reviews in Food Science and Nutrition 55(11), 1503-1513.

Balasundram, N., Sundram, K., Samman, S., 2006. Phenolic compounds in plants and agri-industrial by-products: antioxidant activity, occurrence, and potential uses. Food Chemistry 99(1), 191-203.

Banon, S., Diaz, P., Rodriguez, M., Garrido, M.D., Price, A., 2007. Ascorbate, green tea and grape seed extracts 
increase the shelf life of low sulphite beef patties. Meat Science, 77, 626-633.

Biswas, A.K., Chatli, M.K.,Sahoo, J., 2012. Antioxidant potential of curry (Murraya koenigii L.) and mint (Mentha spicata) leaf extracts and their effect on colour and oxidative stability of raw ground pork meat during refrigeration storage. Food Chemistry 133, 467-472.

Choi, Y.S., Park, K.S., Kim, H.W., Hwang, K.E., Song, D.H., Choi, M.S, Lee, S.Y., Paik, H.D., Kim, C.J., 2013. Quality characteristics of reduced-fat frankfurters with pork fat replaced by sunflower seed oils and dietary fiber extracted from makgeolli lees. Meat Science, 93, 652658.

Correia Da Costa, J.M., Da Costa, C., De Freitas Felipe, M.E., Maia, G.A., Hernandez, F.F.F., Brasil, I.M., 2008. Production and characterization of the cashew apple (Anacardium occidentale L.) and guava (Psidium guajava L.) fruit powders. Journal of Food Processing and Preservation 33(1), 299-312.

Devatkal, S.K., Thorat, P., Manjunatha, M., 2014. Effect of vacuum packaging and pomegranate peel extract on quality aspects of ground goat meat and nuggets. Journal of Food Science and Technology 51(10), 26852691.

Duncan, D.B., 1995. Multiple range and multiple F-tests. Biometrics 11, 1-42.

Georgantelis, D., Blekas, G., Katikou, P., Ambrosiadis, I., Fletouris, D.J., 2007. Effect of rosemary extract, chitosan and -tocopherol on lipid oxidation and colour stability during frozen storage of beef burgers. Meat Science 75, 266-274.

Govaris, A., Solomakos, N., Pexara, A., Chatzopoulou, P.S., 2010. The antimicrobial effect of oregano essential oil, nisin and their combination against Salmonella enteritidis in minced sheep meat during refrigerated storage. International Journal of Food Microbiology 137, 175-180.

Guanghou, S., Leong, L.P., 2004. Analysis of Polyphenolic antioxidant in star fruit using liquid chromatography and mass spectrometry. Journal of Chromatography 1022(12), 67-75.

Haumann, B.F., 1990. AOCS Inform 1, 1002-1013.

Hemaida, M.H., 1994. Isolation of natural antioxidants from vegetables waste by-products. Agricultural Sciences Mansura University 19, 2953-2960.

Hsouna, A.B., Trigui, M., Mansour, R.B., Jarraya, R.M., Damak, M., Jaoua, S., 2011. Chemical composition, cytotoxicity effect and antimicrobial activity of Ceratonia siliqua essential oil with preservative effects against Listeria inoculated in minced beef meat. International Journal of Food Microbiology 148, 66-72.

Jay, J.M., 1992. Spoilage of fresh beef, pork, and related meats. Modern Food Microbiology. $4^{\text {th }}$ ed. Chapman and Hall, New York, 201-205.
Jiménez-Escrig, A., Rincón, M., Pulido, R., Saura-Calixto, F., 2001. Guava Fruit (Psidium guajava L.) as a New Source of Antioxidant Dietary Fiber. Journal of Agricultural Food Chemistry, 49, 5489-5493.

Kanner, J., 1994. Oxidative processes in meat and meat products: Quality implications. Meat Science 36, 169-174.

Kruskal, W.H., Wallis, W.A., 1952. Use of ranks in onecriterion variance analysis. Journal of the American Statistical Association, 47, 583-621.

Masum, M.M., Rahman S.M., Begum K., Begum, B.,Md. Rashid, A., 2007. Phytochemical and Biological studies of Averrhoa carambola. Journal of Pharmacological Science 6(2), 125-128.

Miean, K.H., Mohamed, S., 2001. Flavonoid (myricetin, quercetin, kaempferol, luteolin, and apigenin) content of edible tropical plants. Journal of Agricultural and Food Chemistry 49, 3106-3112.

Misra, K., Seshadri, T.R., 1968. Chemical components of the fruits of Psidium guajava. Phytochemistry 7, 641-645.

Neira, G.A., Ramirez, G.M.B., 2005. Actividad antimicrobiana de extractos de dos especies de guayaba contra Sterptococcus mutans y Escherichia coli. Actualidades Biologicas 27, 27-30.

Patil, A.G., Patil, D.A., Phatak, A.V., Naresh, C., 2010. Physical and chemical characteristics of carambola (Averrhoa carambola L.) fruit at three stages of maturity. International Journal of Applied Biology and Pharmaceutical Technology 1, 624-629.

Pereira, P.M.D.C., Vicente, A.F.D.B., 2013. Meat's nutritional composition and nutritive role in the human diet. Meat Science 93, 586-592.

Shui, G., Leong, L.P., 2006. Residue from starfruit as valuable source for functional food ingredients and nutraceuticals. Food chemistry 97, 277-284.

Tarladgis, B.G., Watts, B.M., Younathan, M.T., Dugan, L.R., 1960. A distillation method for the quantitative determination of malonaldehyde in rancid foods. Journal of American Oil Chemistry Society 37, 44-48.

Tiwari, B.K., Valdramidis, V.P., O'Donnell, C.P., Muthukumarappan, K., Bourke, P., Cullen, P., 2009. Application of natural antimicrobials for food preservation. Journal of Agricultural and Food Chemistry 57(14), 5987-6000.

Verma, S.N., Sahoo, J., 2000. Improvement in the quality of ground chevon during refrigerated storage by tocopherol acetate preblending. Meat Science 56, 403-413.

Zhang, H., Kong, B., Xiong, Y.L., Sun, X., 2009. Antimicrobial activities of spice extracts against pathogenic and spoilage bacteria in modified atmosphere packaged fresh pork and vacuum packaged ham slices stored at 4 ${ }^{\circ} \mathrm{C}$. Meat Science, 81, 686-692. 